\title{
Long-term ecological responses of the River Spöl to experimental floods
}

\author{
Christopher T. Robinson ${ }^{1,3}$, Andre R. Siebers ${ }^{1,4}$, and Johannes Ortlepp ${ }^{2,5}$ \\ Department of Aquatic Ecology, Eawag, 8600 Duebendorf, Switzerland and Institute of Integrative Biology, ETH-Zürich, \\ 8092 Zürich, Switzerland \\ Hydra Büro für Gewässerökologie, Mühlweg 17, D-75223 Öschelbronn, Germany
}

\begin{abstract}
The river Spöl flows from Livigno reservoir on the Swiss-Italian border in the central Alps. Flow regulation since 1970 has decreased and stabilized the mean annual discharge of 8.6 to $1.0 \mathrm{~m}^{3} / \mathrm{s}$ (winter: $0.55 \mathrm{~m}^{3} / \mathrm{s}$, summer: $2.5 \mathrm{~m}^{3} / \mathrm{s}$ ). Thirty experimental floods were released between 2000 and 2016 to improve the ecology of the river. A $100-\mathrm{m}$ reach $\sim 2.3 \mathrm{~km}$ downstream of the dam was used to monitor changes in water physicochemistry, periphyton, transported and benthic organic matter, and macroinvertebrates. Fish redds (native Brown Trout) were counted each autumn along the same stretch $(\sim 2.6 \mathrm{~km})$ of river. Most physicochemical variables displayed strong seasonal cycles unrelated to the flow program, but N, P, and water temperature increased significantly over the 18-y study. Seston decreased after each high flow, but was seasonal and increased over the study. Periphyton biomass decreased after each high flow to low levels and increased between high flows. Benthic organic matter decreased $2 \times$ over the study but increased between floods. Macroinvertebrate densities decreased over the study. High flows reduced macroinvertebrate densities to $<10,000$ individuals (ind) $/ \mathrm{m}^{2}$, with densities usually increasing to $\sim 10,000$ to $20,000 \mathrm{ind} / \mathrm{m}^{2}$ between floods. Floods reduced taxonomic richness with increases between floods. Ordination showed temporal shifts in macroinvertebrate assemblages over the study. Mayflies and stoneflies responded positively and chironomids and gammarids negatively to the floods over the study. Fish redds increased from 58 in 1999 to $>200$ by 2003 . Redd counts decreased to $<30$ after an accidental sediment spill in 2013 but rebounded to 153 redds in 2016. Macroinvertebrate assemblages recovered within months after the spill. Long-term monitoring was essential for elucidating ecosystem dynamics and evaluating biological responses to pulse disturbances, such as the sediment spill, during the study.
\end{abstract}

Key words: environmental flows, macroinvertebrates, periphyton, flood disturbance, Brown Trout, Swiss National Park

Reservoirs are a common feature of today's global landscape with $>55,000$ large dams in place and numerous others being constructed or planned for the future (Nilsson et al. 2005, Vörösmarty et al. 2010). Reservoirs strongly influence the ecohydrology of downstream waters (Ward and Stanford 1979, Bunn and Arthington 2002, Graf 2006, Poff et al. 2007), but only in the last 20 y have resource managers begun to implement flow mitigation policies to restore the character of the natural flow regime in regulated rivers (Konrad et al. 2011, Olden et al. 2014) or have removed dams to improve river connectivity (e.g., Foley et al. 2017). Environmental flows are now quite common across the globe (Arthington 2014), although the primary objectives, from physical to biological, of such flows vary considerably among rivers (Olden et al. 2014, Gillespie et al. 2015). Researchers attempt to link environmental flows to ecosystem processes (Lake et al. 2007, Yarnell et al. 2015) and floodplain function (Rood et al. 2005, Opperman et al. 2010) and, more recently, to integrate riverine thermal and sediment regimes with flow in a more holistic framework (Olden and Naiman 2010, Wohl et al. 2015). What is generally evident from many studies is the use of an adaptive management strategy in the long-term planning of environmental flows, especially as river ecosystem states, data analysis, and learning evolve over time (Cross et al. 2011, Gillespie et al. 2015).

In addition to characterizing background variability and temporal trends, long-term data on the ecological response of regulated rivers to environmental flows can be used to better understand ecological thresholds, tipping points, and regime shifts in river ecosystems (e.g., Robinson 2012). Regulated rivers are fragmented systems (Nilsson et al. 2005). Thus, dispersal mechanisms are pivotal in assessing and understanding ecosystem responses and forecasting potential future trajectories in ecosystem properties following flow manipulations (Lake 2000, Lake et al. 2007), or even ecoevolutionary responses of biota to alterations in ecological

E-mail addresses: ${ }^{3}$ robinson@eawag.ch; ${ }^{4}$ siebers@eawag.ch; ${ }^{5}$ ortleppj@gmail.com

DOI: 10.1086/699481. Received 30 November 2017; Accepted 29 April 2018; Published online 12 July 2018.

Freshwater Science. 2018. 37(3):433-447. ๑ 2018 by The Society for Freshwater Science. 
regimes (sensu Poff et al. 1997, Lytle and Poff 2004, Durance and Ormerod 2007). This ecological understanding is particularly important when incorporating external drivers, such as climate change on observed changes (e.g., Reid and Ogden 2006, Matthews et al. 2013, Thompson et al. 2013, Death et al. 2015, Garssen et al. 2015) or to improve our understanding of ecosystem responses to extreme events, in general, when evaluating long-term data (McMullen and Lytle 2012, Robertson et al. 2015, Woodward et al. 2015). For instance, one can test ecological theory regarding the increased resilience of an ecosystem following long-term environmental manipulation, such as through artificial floods (sensu Robinson 2012), because disturbance is an inherent property of many ecosystems on the globe (Connell 1978).

Environmental legacies, whether natural or human-related, have important implications when evaluating long-term data (Battarbee et al. 2014, Sertić Perić et al. 2015) or inferring cause and effect from management actions such as environmental flows (Lake et al. 2007). For example, environmental flows implemented at the start of a flow program can have different effects than similar high flows conducted years later (Robinson and Uehlinger 2008, Robinson 2012). Legacies, such as the regulatory foundation of a river in which environmental flows are being implemented, provide the inherent ecological footprint of an ecosystem to which biota have adapted (Southwood 1977, 1988) and, thus, influence the response of an ecosystem to external perturbations or extreme events (Harding et al. 1998, Robertson et al. 2015, Woodward et al. 2015). Furthermore, environmental flows may cause different ecological responses in the context of the system in which they occur, e.g., canyon-confined vs more open floodplain rivers (Gillespie et al. 2015). An important aspect is to view environmental flows as large-scale ecosystem experiments (Konrad et al. 2011) and to use them to enhance our learning of ecosystem response to ecological disturbance (sensu Pickett and White 1985), thereby placing environmental flows in a more predictive framework.

A primary objective of our study was to understand how $18 \mathrm{y}$ of sequential experimental floods affected the shortand long-term ecosystem dynamics of the River Spöl. Earlier papers synthesizing the monitoring data were published in 2008 and 2012 (Robinson and Uehlinger 2008, Robinson 2012). This paper adds 5 y of monitoring to the analysis. The floods were initiated primarily to improve habitat conditions in the river for the native Brown Trout (Salmo trutta fario L.), the sole fish inhabiting the river. Our study focuses on how the experimental floods affected long-term dynamics in water physicochemistry, organic-matter resources, macroinvertebrate assemblages, and fish abundances in the river. We expected the experimental floods to cause a shift in macroinvertebrate assemblages to those resembling more alpine stream systems in the region. The floods altered habitat conditions in the river (Robinson 2012), thereby facilitating colonization of taxa adapted to more variable flow condi- tions, such as those found in nearby streams (see Sertić Perić et al. 2015). We also expected trout abundances to increase over time with the observed changes in habitat conditions that improved the potential for reproduction. Earlier floods reduced the embeddedness of the stream bottom (see Robinson et al. 2004), increasing the availability of spawning habitat for trout (Ortlepp and Mürle 2003). No changes were expected in water physicochemistry, but organic-matter resources in the river were expected to decrease in response to the floods. For instance, waters from the reservoir were used for each flood, thus any changes in physicochemistry would be derived from external drivers, e.g., landuse changes in the upper catchment or climate. Furthermore, the floods would effectively reduce organic-matter resources (periphyton, benthic organic matter) in the river bed through the flushing effect of high flows (Robinson et al. 2004). A secondary objective was to examine the recovery of macroinvertebrates and fish following a major sediment spill in the river from Livigno reservoir in 2013 (see below). An expectation of the flood program was an increase in the resilience of the river ecosystem to such pulse disturbances (sensu Lake 2000). We expected macroinvertebrate assemblages to recover rapidly following the extreme disturbance event, whereas native Brown Trout recovery would be slower and dependent on life-history events, such as population recruitment. For instance, Brown Trout in the Spöl begin reproduction after 2 y of development (Ortlepp and Mürle 2003).

\section{Study site description}

The flow-regulated stretch of the Spöl starts downstream of Livigno reservoir on the Swiss-Italian border in the central Alps (lat $46^{\circ} 36^{\prime} 38^{\prime \prime} \mathrm{N}$, long $10^{\circ} 11^{\prime} 22^{\prime \prime} \mathrm{E}$,), flowing from Punt dal Gall dam at the reservoir through a canyon-confined valley in the Swiss National Park for $\sim 5.7 \mathrm{~km}$ before entering the lower Ova Spin reservoir (Fig. 1). Both reservoirs are used for hydropower production (see Scheurer and Molinari 2003). The Spöl merges with the Inn River, a major tributary of the Danube, at the town of Zernez, Switzerland. The study reach is $\sim 2.3 \mathrm{~km}$ downstream of Punt dal Gall at $1660 \mathrm{~m}$ asl. Before regulation in 1970, the Spöl exhibited a typical snowmelt/glacial-melt flow regime with high flows in summer and low flows in winter (Fig. 1). Periodic floods from heavy precipitation usually occurred during summer/early autumn and ranged between 20 and $60 \mathrm{~m}^{3} / \mathrm{s}$. Climate in the region is continental with high seasonal variation in temperature but relatively low precipitation (Barry 1992). Terrestrial vegetation is mainly coniferous forest (Picea excelsa and Pinus mugo) with alder (Alnus incana) a common riparian tree.

The Spöl below Livigno reservoir is part of a complex hydroelectric scheme that became operational in 1970 (Scheurer and Molinari 2003). Flow regulation done with hypolimnetic water from the reservoir decreased the mean annual 


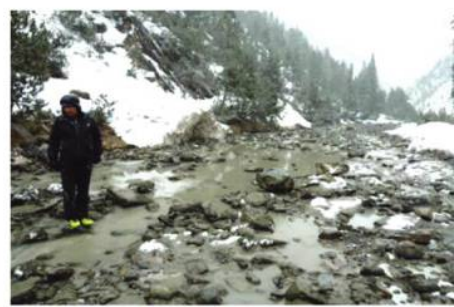

29-30 March 2013

$1.5 \mathrm{~m}^{3} \mathrm{~s}^{-1}$
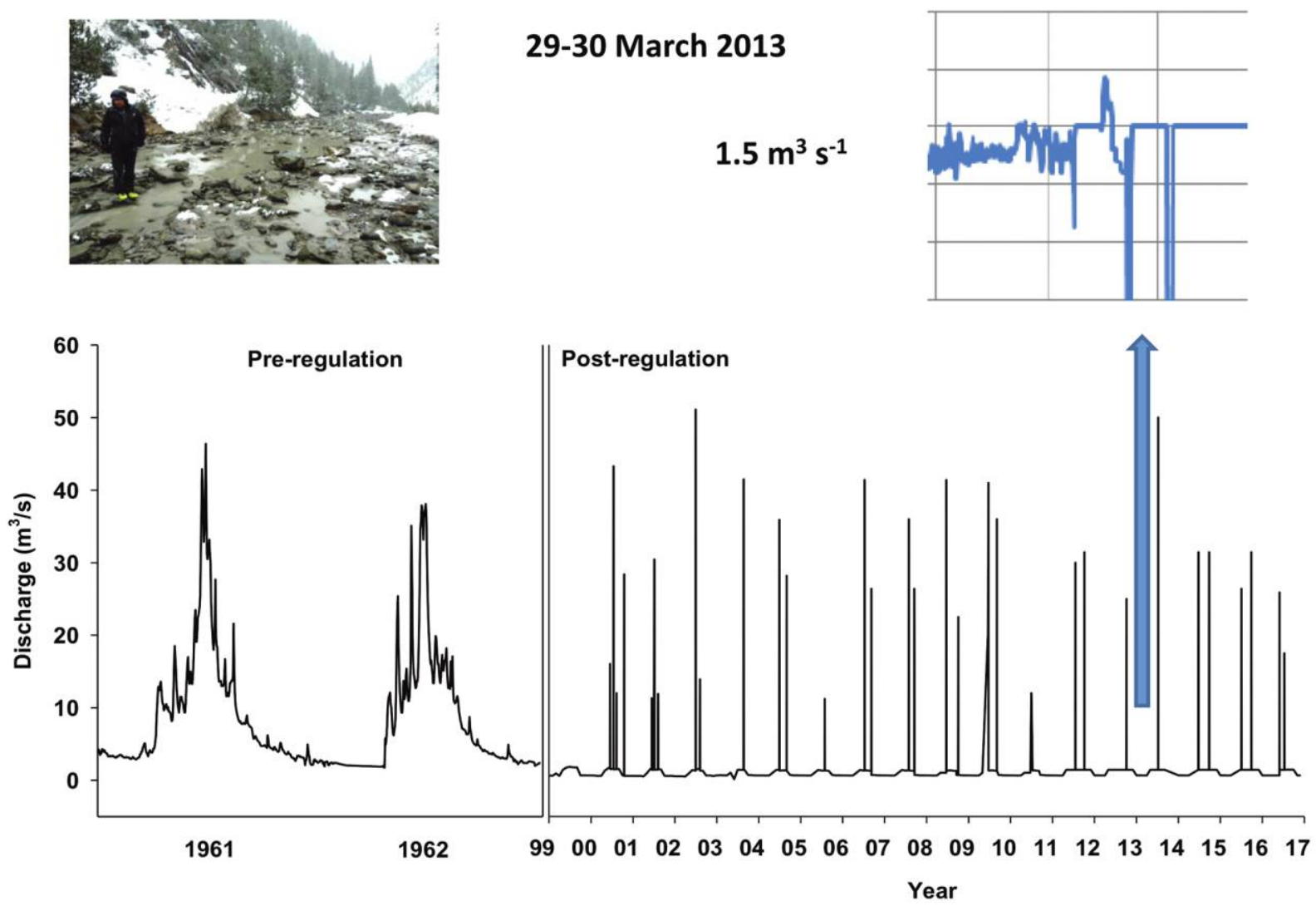

Figure 1. Discharge in the Spöl prior to flow regulation beginning in 1970, a typical post-regulation discharge in 1999, and during the flood program from 2000 to 2017. Inset shows the loss in flow in late March 2013 resulting in a major sediment spill from Livigno reservoir when the lower valve was opened at the dam to resume flows in the river. The high flow in July 2013 was used to flush the fine sediments deposited in the residual section of the Spöl following the spill once sufficient water was available for release. Inset photo is of the Spöl during this loss in flow in March 2013.

discharge from 8.6 to $1.0 \mathrm{~m}^{3} / \mathrm{s}$, averaging $0.55 \mathrm{~m}^{3} / \mathrm{s}$ in winter and $2.5 \mathrm{~m}^{3} / \mathrm{s}$ in summer (Fig. 1). The residual flows lacked the power to entrain and transport coarse sediments, thereby allowing the riverbed to become clogged with fine sediments (Ortlepp and Mürle 2003) and large pools to form upstream of lateral debris fans (Mürle et al. 2003). The constant flows resulted in dense algal mats, extensive moss beds, and an invertebrate assemblage dominated by the crustacean Gammarus fossarum (Robinson et al. 2003). Gammarus densities before the flood program ranged from 8000 to 15,000 individuals (ind) $/ \mathrm{m}^{2}$ at the study reach (Robinson and Uehlinger 2008, Robinson 2012) and were an important resource for the trout fishery (Ortlepp and Mürle 2003). The native Brown Trout (Salmo trutta fario L.) were low in number because of a lack of suitable spawning habitat that resulted from colmation of the stream bed (Ortlepp and Mürle 2003). The Engadine power company, the National Park, and state authorities began using experimental floods in 2000 to improve habitat conditions for the Brown Trout (Scheurer and Molinari 2003). Residual flows were reduced $\left(0.55 \mathrm{~m}^{3} / \mathrm{s}\right.$ winter, $1.45 \mathrm{~m}^{3} / \mathrm{s}$ summer) beginning in 1999 to compensate for water used for the floods (Uehlinger et al. 2003). Two post-regulation floods occurred in 1979 at $42 \mathrm{~m}^{3} / \mathrm{s}$ and in 1990 at $33 \mathrm{~m}^{3} / \mathrm{s}$ prior to implementation of the program in 2000 (Scheurer and Molinari 2003). The floods are relatively cost neutral because of the network of reservoirs, aqueducts, and power houses that re-allocate water for power production while maintaining residual flows in the river.

Thirty-two separate floods were released between 2000 and the end of 2016. Timing and magnitude depended on research needs and water availability (Fig. 1). Controlled floods lasted 6 to $8 \mathrm{~h}$ with step-like rising and falling limbs constrained by release-valve mechanics. Actual peak flows usually lasted 2 to $3 \mathrm{~h}$ with the falling limb designed to be relatively gradual to minimize fish stranding. Although shorter than most natural floods, the high flows effectively mobilized bed sediments and reduced algal levels without causing high fish mortality (Ortlepp and Mürle 2003, Uehlinger et al. 2003).

The flood program started with 3 floods each in 2000 and 2001 and alternated between 1 and 2 floods flood/y from 
2002 to 2016. The floods in 2000 and 2001 consisted of 2 smaller flows between 12 and $16 \mathrm{~m}^{3} / \mathrm{s}$ in June and August that bounded a higher flow (42 and $55 \mathrm{~m}^{3} / \mathrm{s}$, respectively) in July. An unplanned flood in October 2000 resulted from heavy rainfall and caused a 3-d release of surplus water that peaked at $28 \mathrm{~m}^{3} / \mathrm{s}$. After 2002, the June flood was eliminated. In years with 2 floods, a high flow usually occurred in July $\left(>30 \mathrm{~m}^{3} / \mathrm{s}\right.$ ) with a smaller flushing flow released in late August/early September (15-25 m³ $/ \mathrm{s}$ ) (see Fig. 1). Single floods were implemented in $2003\left(41.5 \mathrm{~m}^{3} / \mathrm{s}\right), 2005\left(11.2 \mathrm{~m}^{3} / \mathrm{s}\right)$, $2010\left(37 \mathrm{~m}^{3} / \mathrm{s}\right) 2012\left(26 \mathrm{~m}^{3} / \mathrm{s}\right)$ to meet research needs or from low water. A single flood in $2013\left(50 \mathrm{~m}^{3} / \mathrm{s}\right)$ was used as a flushing flow to remove fine sediments accidently released from the reservoir earlier that spring (Task Force Spöl 2015). The sediment spill negatively affected the fishery and macroinvertebrate assemblages in the river as discussed below. A 4-d flushing flow also was released from 19-22 June 2009 that peaked at $41 \mathrm{~m}^{3} / \mathrm{s}$.

\section{METHODS}

\section{Long-term monitoring}

A 100 -m long reach $\sim 2.3 \mathrm{~km}$ downstream of the dam was used during the $18 \mathrm{y}$ of study and was accessed via a national park trail. Flow was recorded at a gauging station downstream of Punt Dal Gall dam by the Federal Office of Hydrology and Geology. A temperature logger (Minilog; Vemco, Nova Scotia, Canada) was installed at the study site and recorded temperature at 1 -h intervals. The site was visited 148 times during the study (1999-2016) for collection of samples. Samples were collected every 3 to $5 \mathrm{wk}$ when accessible for the long-term study, along with samples intentionally collected 1 to $3 \mathrm{~d}$ before and 1 to $2 \mathrm{~d}$ after particular floods to examine short-term responses. The actual sampling frequency varied among years, depending on site access and specific research needs.

On each sampling visit, a $0.5-\mathrm{L}$ water sample was collected in a polypropylene bottle for analysis of $\mathrm{NO}_{3}-\mathrm{N}$, particulate $\mathrm{N}(\mathrm{PN})$, orthophosphorus $\left(\mathrm{PO}_{4}-\mathrm{P}\right)$, dissolved $\mathrm{P}(\mathrm{DP})$, particulate $\mathrm{P}(\mathrm{PP})$, total inorganic $\mathrm{C}$ (TIC), dissolved organic $\mathrm{C}$ (DOC), and particulate organic C (POC) following methods detailed by Tockner et al. (1997). In the field, water turbidity (nephelometric turbidity units; NTU) (Cosmos, Züllig AG, Switzerland), pH (WTW 3110, Weilheim, Germany), temperature and electrical conductivity $\left(\mu \mathrm{S} / \mathrm{cm}\right.$ at $\left.20^{\circ} \mathrm{C}\right)$ (WTW LF340, Weilheim, Germany) were measured using portable meters. Transported organic matter (seston, $n=3$ ) was collected on each visit using a $1-\mathrm{m}$-long net $(11-\mathrm{cm}$ diameter, $100-\mu \mathrm{m}$ mesh). All macroinvertebrates were removed from each seston sample before processing. The ash-free dry mass (AFDM) of each sample was estimated by drying the sample at $60^{\circ} \mathrm{C}$, weighing, burning at $500^{\circ} \mathrm{C}$ for $4 \mathrm{~h}$, and reweighing. Flow was measured at the net aperture with a velocity meter (MiniAir2, Schiltknecht AG, Switzerland) to calculate the volume of water filtered for each sample.
Periphyton was measured by randomly collecting 10 stones (cobble-size) from the study reach on each visit. The stones were placed in plastic bags, returned to the laboratory, frozen at $-20^{\circ} \mathrm{C}$, and processed $<3$ to 4 wk after collection. Periphyton was removed from each stone by scrubbing with a wire brush into a bucket with water, and the $a$-, $b$ - and $c$-axis of each stone was measured with a caliper (after Uehlinger 1991). An aliquot of the periphyton suspension was filtered through a glass-fiber filter (Whatman GF/F, precombusted at $450^{\circ} \mathrm{C}$ ). The filter was dried at $60^{\circ} \mathrm{C}$, weighed, burned at $500^{\circ} \mathrm{C}$ for $4 \mathrm{~h}$, and reweighed to estimate AFDM.

Benthic macroinvertebrates were collected from rifflerun habitats on each visit $(n=3)$ with a Hess sampler $\left(0.045 \mathrm{~m}^{2}, 250-\mu \mathrm{m}\right.$ mesh). Benthic samples were taken to a depth of 15 to $20 \mathrm{~cm}$ and all large stones scrubbed by hand to remove invertebrates before processing. Samples were stored in plastic bottles and preserved in the field with $70 \%$ ethanol. In the laboratory, macroinvertebrates were handpicked from each sample with the aid of a dissecting microscope at $10 \times$ magnification, identified to lowest practical taxonomic unit (usually genus), and counted (macroinvertebrate biomass was not measured in our study). The remaining material from each benthic sample was dried at $60^{\circ} \mathrm{C}$, weighed, burned at $500^{\circ} \mathrm{C}$ for $4 \mathrm{~h}$, and reweighed. The difference in mass was used as an estimate of benthic organic material (BOM as AFDM).

Trout abundance was estimated via annual monitoring of spawning redds in the $2.6-\mathrm{km}$ stretch below Punt dal Gall dam. Brown Trout spawn in late autumn (November), and the redds are easily seen (as denuded areas) and can be counted (JO, personal observation; Beland 1996, Riebe et al. 2014). Redds were counted and mapped via a global positioning system (GPS) each autumn by park officials under residual flow conditions $\left(\sim 1.5 \mathrm{~m}^{3} / \mathrm{s}\right)$ when water depth was $\sim 20$ to $30 \mathrm{~cm}$ and water clarity was typically good ( $<10$ NTU). Redd counts were used as an index of reproductive success of the trout over the study period (assuming food was not limiting; e.g., Beland 1996, Riebe et al. 2014) and not an actual measure of trout abundance in the river (electrofishing is forbidden in the Swiss National Park; R. Haller, personal communication).

\section{Flushing flow of 2013}

A major sediment spill occurred in the river on 30 March 2013 (Task Force Spöl 2015). Water in the reservoir reached low levels that resulted in no water being released from the reservoir for a number of days ( 4-5 $\mathrm{d}$ in the last week of March 2013). Once the lack of flow was noticed by park officials, the lower release valve was opened at Punt dal Gall dam to release water to the river. This opening, in fact, released a large volume of fluvial fine sediments that had accumulated in the reservoir and which then covered the river bed between the 2 reservoirs once released. The spill killed most Brown Trout ( 64\%) and covered benthic sediment 
and invertebrates. Once enough water was available (9 July 2013), the Park authorized a flushing flow to remove fine sediments from the river bed to minimize further ecological consequences to the river. To document direct responses to the flushing flow, various measures were collected at frequent intervals during the event. These measures included discharge, turbidity as an indicator of suspended sediments, transported organic matter (seston), and macroinvertebrate drift. Seston and drift were collected with an 80-cm long net (400- $\mu \mathrm{m}$ mesh, $10-\times 30$-cm aperture) with flow measured at the net mouth (MiniAir2 velocity meter; Schiltknecht Messtechnik AG, Gossau, Switzerland) to calculate the volume of water filtered. In the laboratory, macroinvertebrates were handpicked from each sample and the remaining material used for determination of seston as AFDM as described above.

\section{Data analysis}

Physicochemical and organic matter resources (seston, periphyton, benthic organic material) data were summarized initially as means, standard deviations (SD) and coefficients of variation (CV), and examined for temporal patterns. Macroinvertebrates were summarized as above in terms of density, taxonomic richness, and the densities of 6 common taxa (Chironomidae, Gammarus sp., Baetis spp., Protonemura spp., Leuctra spp., and Nemoura spp.). Generalized additive models (GAMs) were used to describe the changes in measured variables through time. An autocorrelation structure based on the total days since the start of the flood program in 2000 was included to account for temporal correlation. Analysis began with models containing all possible explanatory terms and their interactions, and the term with the lowest explanatory value was dropped stepwise until all model terms were significant at $p<0.05$. The models were run with the package $m g c v$ in $\mathrm{R}$ (version 3.42; R Project for Statistical Computing, Vienna, Austria). In addition, a nonmetric multidimensional scaling (NMDS) analysis was run based on the $\arcsin \sqrt{ }(x)$-transformed relative abundance data of macroinvertebrates to illustrate temporal changes in assemblage composition during the study period. The number of trout redds counted each year was plotted against time to examine for temporal changes in fish abundance, as a relative index of reproductive success (Beland 1996, Riebe et al. 2014). Last, individual measures (e.g., seston, drift, turbidity) collected during the flushing flow of 2013 were plotted against time and discharge during the duration of the flood.

\section{RESULTS}

\section{Water physicochemistry}

Over the 18 y of study, mean DOC was $0.80 \mathrm{mg} / \mathrm{L}(\mathrm{CV}=$ $55 \%)$, POC was $0.68 \mathrm{mg} / \mathrm{L}(\mathrm{CV}=84 \%)$, and TIC was $20.9 \mathrm{mg} / \mathrm{L}(\mathrm{CV}=14 \%)$. Mean water temperature was $7.5^{\circ} \mathrm{C}$ $(\mathrm{CV}=28 \%$; Figs $2 \mathrm{~A}, \mathrm{~S} 1 \mathrm{~A})$, mean $\mathrm{pH}$ was $7.1(\mathrm{CV}=8 \%)$, mean conductivity was $255 \mu \mathrm{S} / \mathrm{cm}(\mathrm{CV}=11 \%$; Figs $2 \mathrm{~B}, \mathrm{~S} 1 \mathrm{~B})$, and mean turbidity was $12.8 \mathrm{NTU}(\mathrm{CV}=121 \%)$. Mean PN was $35 \mu \mathrm{g} / \mathrm{L}(\mathrm{CV}=136 \%)$ and $\mathrm{PP}$ was $5.5 \mu \mathrm{g} / \mathrm{L}(\mathrm{CV}=106 \%)$ (PN and PP not measured after 2011). Mean $\mathrm{NO}_{3}{ }^{-}-\mathrm{N}$ was $256 \mathrm{mg} / \mathrm{L}(\mathrm{CV}=18 \%$; Figs 2C, S1C) and mean DP was $4.6 \mu \mathrm{g} / \mathrm{L}$ (Figs 2D, S1D). In general, water temperature, $\mathrm{NO}_{3}{ }^{-}-\mathrm{N}$, and DP peaked in summer and had low values in winter, whereas conductivity was low in autumn and high in spring/summer (GAM, $p<0.05$; Table 1, Fig. S1A-D). $\mathrm{NO}_{3}{ }^{-}-\mathrm{N}, \mathrm{DP}$, and water temperature significantly increased over the $18-\mathrm{y}$ study period (Table 1 ).

\section{Organic matter resources (seston, periphyton, BOM)}

Seston levels significantly increased in each year and over the duration of the study (GAM, $p<0.05$; Table 1, Fig. 3A). Seston levels typically increased between high-flow events during the study period (Fig. S2A). Four substantial peaks $\left(>250 \mathrm{mg} / \mathrm{m}^{3}\right)$ in seston were recorded during the study. Except for the 2013 peak, which was associated with the sediment spill that spring, peaks were associated with local precipitation events that caused inputs of organic matter from side-slopes and tributaries into the main Spöl channel.

Periphyton levels before the program in 1999 were, on average, $\sim 30 \mathrm{~g} / \mathrm{m}^{2}$ (Figs 3B, S2B). As with seston, periphyton biomass decreased significantly after each flow event to low levels $\left(<5.0 \mathrm{~g} / \mathrm{m}^{2}\right)$, but quickly recovered to higher levels prior to the next flow event (GAM, $p<0.05$; Table 1, Figs. 3B, $\mathrm{S} 2 \mathrm{~B})$. Extremely high values $\left(>90 \mathrm{~g} / \mathrm{m}^{2}\right)$ were observed in 2001-2002 after the September high flow, perhaps as an early ecosystem response to the environmental flows. Another periphyton peak $\left(\sim 90 \mathrm{~g} / \mathrm{m}^{2}\right)$ was observed in June 2013 (as with seston) prior to the flushing flow in early July 2013 that removed fine sediments resulting from the accidental spill (see below; Fig. S2B). The GAM analysis also revealed a significant correlation of periphyton biomass with levels of DP in the river (Table 1).

The amount of benthic organic matter (BOM) was, on average, $\sim 18 \mathrm{~g} / \mathrm{m}^{2}$ before the flood program started in 1999 (Fig. 3C). The amount of BOM decreased $\sim 2 \times$ (usually $<5.0 \mathrm{~g} / \mathrm{m}^{2}$ ) over the study period (GAM, $p<0.05$; Table 1 , Figs 3C, S2C). High BOM levels were found during 20012003 , attaining levels as high as or higher $\left(>20 \mathrm{~g} / \mathrm{m}^{2}\right)$ than before the flood program (Fig. S2C). As with the other organic resources, BOM also increased between floods (GAM, $p<0.05$ ), often reaching values $\sim 10 \mathrm{~g} / \mathrm{m}^{2}$ before the next high-flow event. BOM increased noticeably after the sediment spill in 2013 to levels similar to those in 1999 (i.e., $15-20 \mathrm{~g} / \mathrm{m}^{2}$ ) prior to the flushing flow that summer that reduced levels again to $<5.0 \mathrm{~g} / \mathrm{m}^{2}$ (Fig. S2C).

\section{Macroinvertebrate assemblages}

Macroinvertebrate densities before the flood program in 1999 were, on average, $\sim 24,000 \mathrm{ind} / \mathrm{m}^{2}$ (Figs 4A, S3A). The high flows typically reduced mean values to $<10,000 \mathrm{ind} / \mathrm{m}^{2}$, 

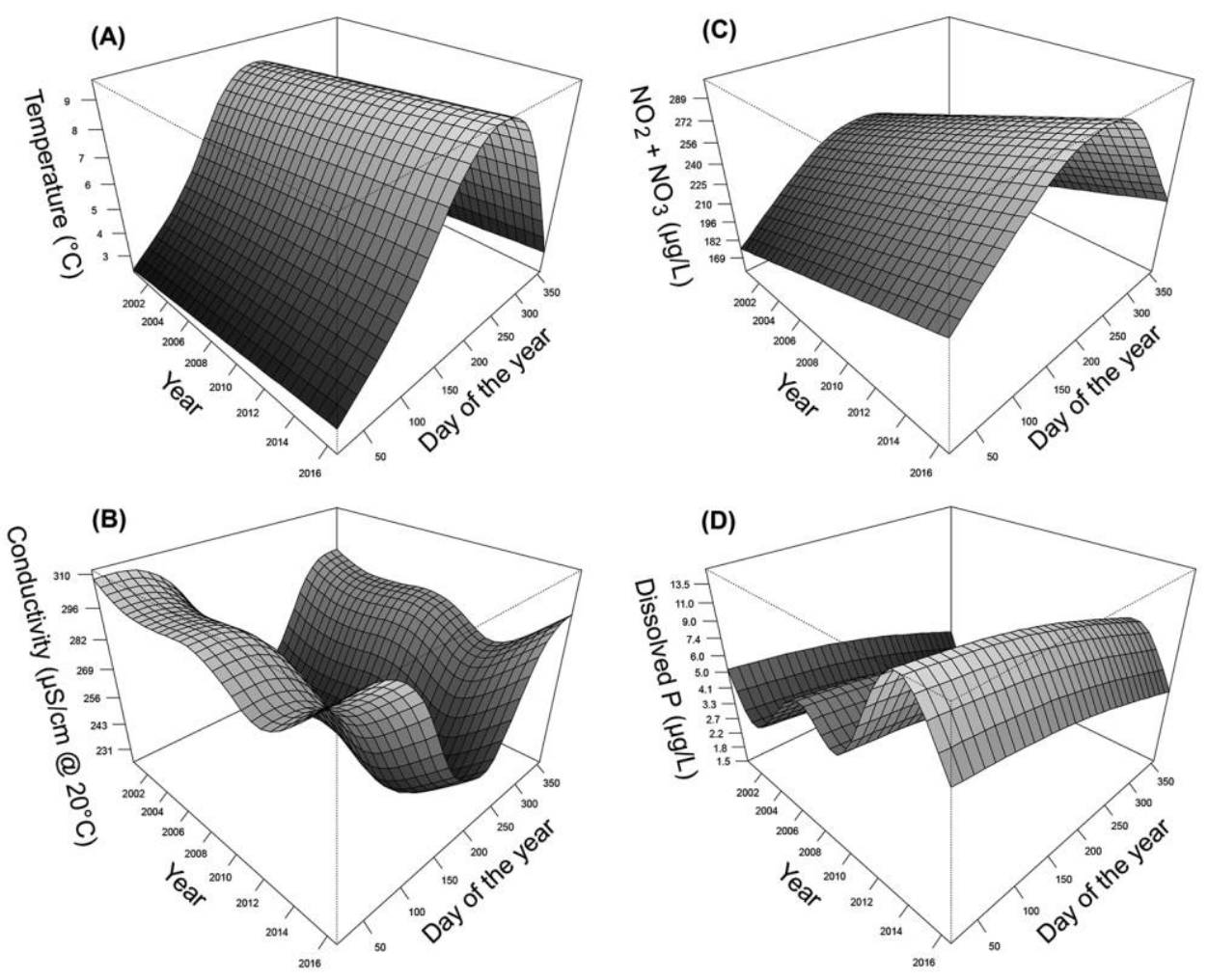

Figure 2. Three-dimensional plots of significant model parameters (generalized additive models [GAMs]) for temperature (A), electrical conductivity (B), $\mathrm{NO}_{3}{ }^{-}-\mathrm{N}(\mathrm{C})$, and dissolved P (DP) (D) in the Spöl during the study period. See Table 1 for statistical summary of the GAM results.

with densities increasing to $\sim 10,000-20,000 \mathrm{ind} / \mathrm{m}^{2}$ between floods (GAM, $p<0.05$; Table 1, Fig. 4A). Densities after floods often reached those found in 1999, in particular in 2000-2005 and 2011-2014 (Fig. S3A). Mean densities $<10,000 \mathrm{ind} / \mathrm{m}^{2}$ were observed between $2006-2010$ and after 2014. The sediment spill in 2013 had little noticeable effect on densities with values reaching $>20,000 \mathrm{ind} / \mathrm{m}^{2}$ in late 2013 after the flushing flow (Fig. S3A).

Mean macroinvertebrate taxonomic richness was $\sim 12$ in 1999, the year before the flood program (Figs 4B, S3B). The floods reduced taxon richness to, on average, $<10$ taxa between 2000 and 2010, with richness values typically increasing between floods as with the other measured variables (GAM, $p<0.05$; Table 1). Between 2010 and 2015, taxonomic richness increased in general to values $>10$ taxa on average (Figs 4B, S3B). Taxonomic richness decreased noticeably in 2015 to $\sim 6$ to 7 taxa. This decrease was reflected in the lower densities occurring at this time (Fig. S3A). The sediment spill in 2013 had no observed effect on macroinvertebrate taxonomic richness in the river.

Six taxa were sufficiently abundant to examine density trends during the study. Chironomidae density was, on average, $\sim 9000 \mathrm{ind} / \mathrm{m}^{2}$ in 1999 , and decreased significantly to $<5000 \mathrm{ind} / \mathrm{m}^{2}$ once the flood program was started (GAM, $p<0.05$; Table 1, Figs 5A, S4A). High densities were observed in 2000-2003 $\left(>15,000 \mathrm{ind} / \mathrm{m}^{2}\right)$ with peaks $>10,000 \mathrm{ind} / \mathrm{m}^{2}$ also found in 2005, 2007, and 2013 (Fig. S4A). Low densities $\left(<200 \mathrm{ind} / \mathrm{m}^{2}\right)$ were always found after each high-flow event, with densities increasing between floods (GAM, $p<0.05$, Fig. 5A).

Gammarus was highly abundant before the flood program in 1999 with densities, on average, $~ 8000 \mathrm{ind} / \mathrm{m}^{2}$ (Figs 5B, S4B). Maximum densities were $\sim 15,000$ to $20,000 \mathrm{ind} / \mathrm{m}^{2}$ at this time. The floods reduced Gammarus densities, on average, to $<1000 \mathrm{ind} / \mathrm{m}^{2}$ with numbers increasing between floods (GAM, $p<0.05$; Table 1, Fig. S4B). Density peaks were observed in $2003\left(>15,000 \mathrm{ind} / \mathrm{m}^{2}\right)$ and 2005 (>5000 ind/ $\mathrm{m}^{2}$ ) when only single floods were implemented. Gammarus densities also increased to $>5000 \mathrm{ind} / \mathrm{m}^{2}$ in $2011-2012$ with a decrease in 2013-2014 (perhaps in response to the sediment spill in 2013), then increased again in 2015-2016 to $>5000 \mathrm{ind} / \mathrm{m}^{2}$ (GAM, $p<0.05$; Figs 5B, S4B).

Baetis mayfly densities were low before the flood program, on average, $\sim 1200 \mathrm{ind} / \mathrm{m}^{2}$ (Figs $5 \mathrm{C}, \mathrm{S} 4 \mathrm{C}$ ). Densities increased substantially between 2000 and 2005 to $>4000$ ind/ $\mathrm{m}^{2}$, decreased on average to $\sim 1000 \mathrm{ind} / \mathrm{m}^{2}$ between 2006 and 2010 , then increased again to $\sim 3000-4000 \mathrm{ind} / \mathrm{m}^{2}$ between 2010 and 2012 (GAM, $p<0.05$; Table 1). After 2012, Baetis densities ranged between 1000 and $3000 \mathrm{ind} / \mathrm{m}^{2}$. Densities were quite low after the sediment spill in 2013 $\left(\sim 100 \mathrm{ind} / \mathrm{m}^{2}\right)$, but increased again after 2013 to $\sim 2000 \mathrm{ind} /$ $\mathrm{m}^{2}$ (Fig. S4C). 
Table 1. Predictor variables chosen to create generalized additive models (GAMs) for each measured variable, with metrics of model fit $\left(R^{2}\right.$ and Akaike Information Criterion [AIC]). Ind = individual.

\begin{tabular}{|c|c|c|c|c|c|}
\hline Response & Distribution & Predictors & Predictor $p$-value & AIC & $R^{2}$ (adj) \\
\hline \multirow[t]{2}{*}{$\mathrm{NO}_{2}{ }^{-}+\mathrm{NO}_{3}{ }^{-}(\mu \mathrm{g} / \mathrm{L})$} & \multirow[t]{2}{*}{ Gaussian } & Sampling date & $<0.001$ & \multirow[t]{2}{*}{385.71} & \multirow[t]{2}{*}{0.32} \\
\hline & & Day of the year & $<0.001$ & & \\
\hline \multirow[t]{2}{*}{ Dissolved P $(\mu \mathrm{g} / \mathrm{L})$} & \multirow[t]{2}{*}{ Poisson } & Sampling date & $<0.001$ & \multirow[t]{2}{*}{283.31} & \multirow[t]{2}{*}{0.43} \\
\hline & & Day of the year & 0.022 & & \\
\hline \multirow[t]{2}{*}{ Temperature $\left({ }^{\circ} \mathrm{C}\right)$} & \multirow[t]{2}{*}{ Gaussian } & Sampling date & 0.027 & \multirow[t]{2}{*}{387.91} & \multirow[t]{2}{*}{0.67} \\
\hline & & Day of the year & $<0.001$ & & \\
\hline \multirow[t]{2}{*}{ Conductivity $(\mu \mathrm{S} / \mathrm{cm})$} & \multirow[t]{2}{*}{ Gaussian } & Sampling date & 0.007 & \multirow[t]{2}{*}{226.83} & \multirow[t]{2}{*}{0.51} \\
\hline & & Day of the year & $<0.001$ & & \\
\hline Seston $(\mathrm{mg} / \mathrm{m})$ & Poisson & Sampling date $\times$ day of the year & $<0.001$ & 237.11 & 0.41 \\
\hline \multirow{2}{*}{ Periphyton $\left(\mathrm{g} / \mathrm{m}^{2}\right)$} & \multirow[t]{2}{*}{ Poisson } & Days since last flood & $<0.001$ & \multirow[t]{2}{*}{206.47} & \multirow[t]{2}{*}{0.44} \\
\hline & & Dissolved P & $<0.001$ & & \\
\hline \multirow[t]{2}{*}{ Benthic organic matter $\left(\mathrm{g} / \mathrm{m}^{2}\right)$} & \multirow[t]{2}{*}{ Poisson } & Sampling date & 0.004 & \multirow[t]{2}{*}{246.95} & \multirow[t]{2}{*}{0.44} \\
\hline & & Sampling date $\times$ days since last flood & $<0.001$ & & \\
\hline \multirow[t]{2}{*}{ Macroinvertebrate density (ind $/ \mathrm{m}^{2}$ ) } & \multirow[t]{2}{*}{ Poisson } & Sampling date & $<0.001$ & \multirow[t]{2}{*}{274.00} & \multirow[t]{2}{*}{0.42} \\
\hline & & Days since last flood & $<0.001$ & & \\
\hline \multirow[t]{2}{*}{ Macroinvertebrate richness } & Gaussian & Sampling date & 0.003 & 484.37 & 0.18 \\
\hline & & Days since last flood & 0.035 & & \\
\hline Chironomidae (ind $/ \mathrm{m}^{2}$ ) & Poisson & Sampling date & $<0.001$ & 374.95 & 0.42 \\
\hline & & Days since last flood & $<0.001$ & & \\
\hline & & Day of the year & 0.001 & & \\
\hline Gammarus sp. (ind $/ \mathrm{m}^{2}$ ) & Poisson & Sampling date & $<0.001$ & 200.21 & 0.40 \\
\hline & & Days since last flood & $<0.001$ & & \\
\hline Baetis sp. (ind/m²) & Poisson & Sampling date & $<0.001$ & 319.71 & 0.66 \\
\hline & & Sampling date $\times$ days since last flood & $<0.001$ & & \\
\hline Protonemura sp. (ind $/ \mathrm{m}^{2}$ ) & Poisson & Sampling date & $<0.001$ & 282.84 & 0.76 \\
\hline & & Days since last flood & 0.017 & & \\
\hline & & Day of the year $\times$ days since last flood & $<0.001$ & & \\
\hline Leuctra sp. (ind/m²) & Poisson & Sampling date & $<0.001$ & 365.01 & 0.80 \\
\hline & & Days since last flood & $<0.001$ & & \\
\hline & & Day of the year & $<0.001$ & & \\
\hline Nemoura sp. (ind $/ \mathrm{m}^{2}$ ) & Poisson & Sampling date & $<0.001$ & 278.49 & 0.90 \\
\hline & & Days since last flood & 0.002 & & \\
\hline & & Day of the year & $<0.001$ & & \\
\hline
\end{tabular}

Three stoneflies displayed contrasting response patterns to the floods. Protonemura stoneflies had densities near 0 ind/ $\mathrm{m}^{2}$ in 1999 . Densities increased substantially after the initial floods $\left(>5000\right.$ ind $\left./ \mathrm{m}^{2}\right)$ and then gradually decreased over the study period to $<50 \mathrm{ind} / \mathrm{m}^{2}$ (GAM, $p<0.05$; Table 1 , Figs 5D, S4D). Densities also decreased during each year of the study. No effects of the sediment spill in 2013 were observed on Protonemura. Leuctra stonefly densities were $\sim 50 \mathrm{ind} / \mathrm{m}^{2}$ in 1999 before the flood program, and densities increased, on average, to $\sim 6000 \mathrm{ind} / \mathrm{m}^{2}$ in 2001 (Figs 5E, $\mathrm{S} 4 \mathrm{E})$. Densities then decreased to near $0 \mathrm{ind} / \mathrm{m}^{2}$ from 2001 to 2006, followed by sharp increases between floods from 2007 to 2016 (GAM, $p<0.05$ ). Densities in these later peaks ranged from 2000 to $9000 \mathrm{ind} / \mathrm{m}^{2}$ with decreases to $<50$ ind/ $\mathrm{m}^{2}$ after each flood. Leuctra densities were highest in spring and autumn (GAM, $p<0.05$; Table 1, Fig. 5E). Nemoura stonefly densities were low or near $0 \mathrm{ind} / \mathrm{m}^{2}$ in 1999 and remained low or absent until 2008 (Figs 5F, S4F). From 2008 to 2011, peak densities between floods ranged from 2000 to $7000 \mathrm{ind} / \mathrm{m}^{2}$ with densities again decreasing to low levels $\left(\sim 20 \mathrm{ind} / \mathrm{m}^{2}\right)$ from 2012 to 2015 with another peak $>2000$ ind $/ \mathrm{m}^{2}$ in 2016 (GAM, $p<0.05$; Table 1, Figs 5F, S4F). Nemoura numbers decreased during each year of the study and were lowest in summer. The sediment spill in 2013 had no major effect on Leuctra or Nemoura densities in the river. 


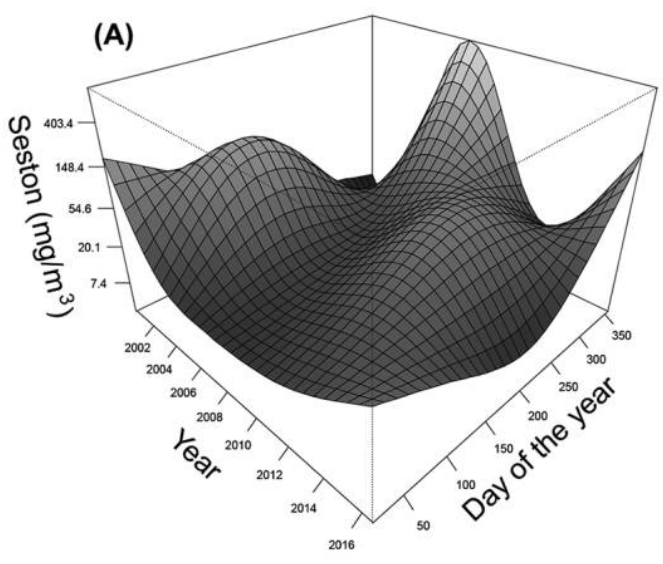

2006 followed by a different assemblage present in 20072010. A $3^{\text {rd }}$ assemblage shift occurred in 2011-2012 with assemblages reset in 2013 after the sediment spill to those found in 2001-2002. Between 2014 and 2016, macroinvertebrate assemblages had returned to those of 2011-2012 before the 2013 sediment spill (Fig. 6).
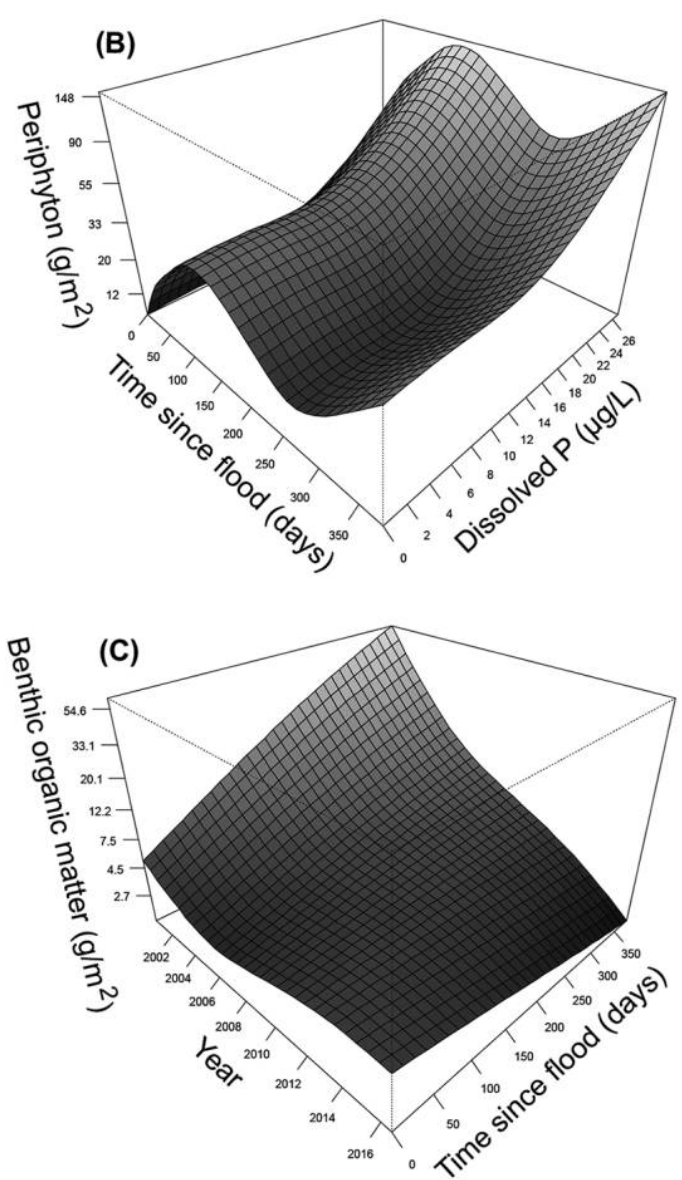

Figure 3. Three-dimensional plots of significant model parameters (generalized additive models [GAMs]) for seston (A), periphyton (B) and benthic organic matter (C) as ash-free dry mass (AFDM). See Table 1 for statistical summary of the GAM results.

The NMDS analysis revealed clear temporal shifts in the composition of the macroinvertebrate assemblage in the Spöl during the study period (Fig. 6). Macroinvertebrates shifted from the preflood assemblage in 1999-2000 to a different assemblage in 2001-2002. Another transition in assemblage composition occurred from 2001-2002 to 2003-

\section{Brown Trout abundance (redd counts)}

The number of fish redds increased from 58 in 1999, the year before the flood program started, to $>200$ by 2003 , the $4^{\text {th }}$ year into the program (Fig. 7). This increase represents 230-40 new redds counted each year between 2000 and 2003. The number of redds fluctuated between 150 and 307 between 2003 and 2012, with low counts attributed to poor conditions for viewing redds for accurate counting (JO, personal observation). After the sediment spill in the river, the redd count decreased to 38 because of the massive killoff of trout in the river from the input of fine sediments
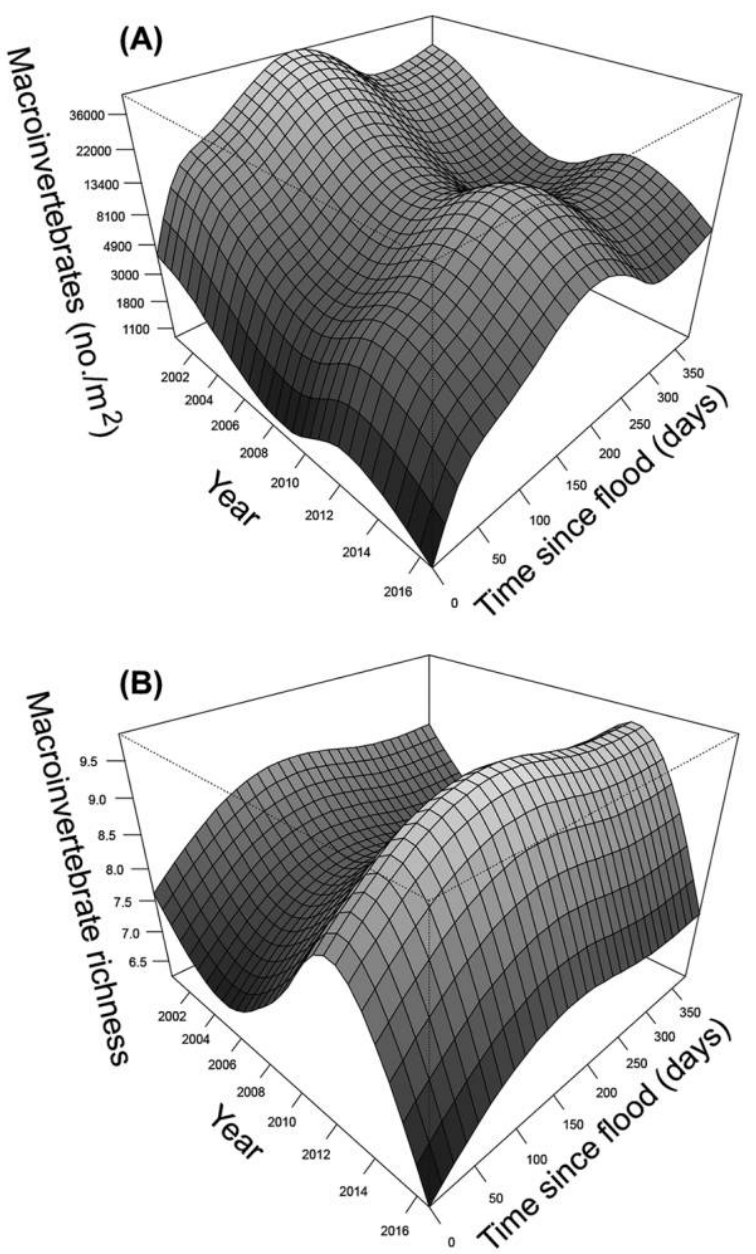

Figure 4. Three-dimensional plots of significant model parameters (generalized additive models [GAMs]) for macroinvertebrate density (A) and taxonomic richness (B) in the Spöl during the study period. See Table 1 for statistical summary of the GAM results. 

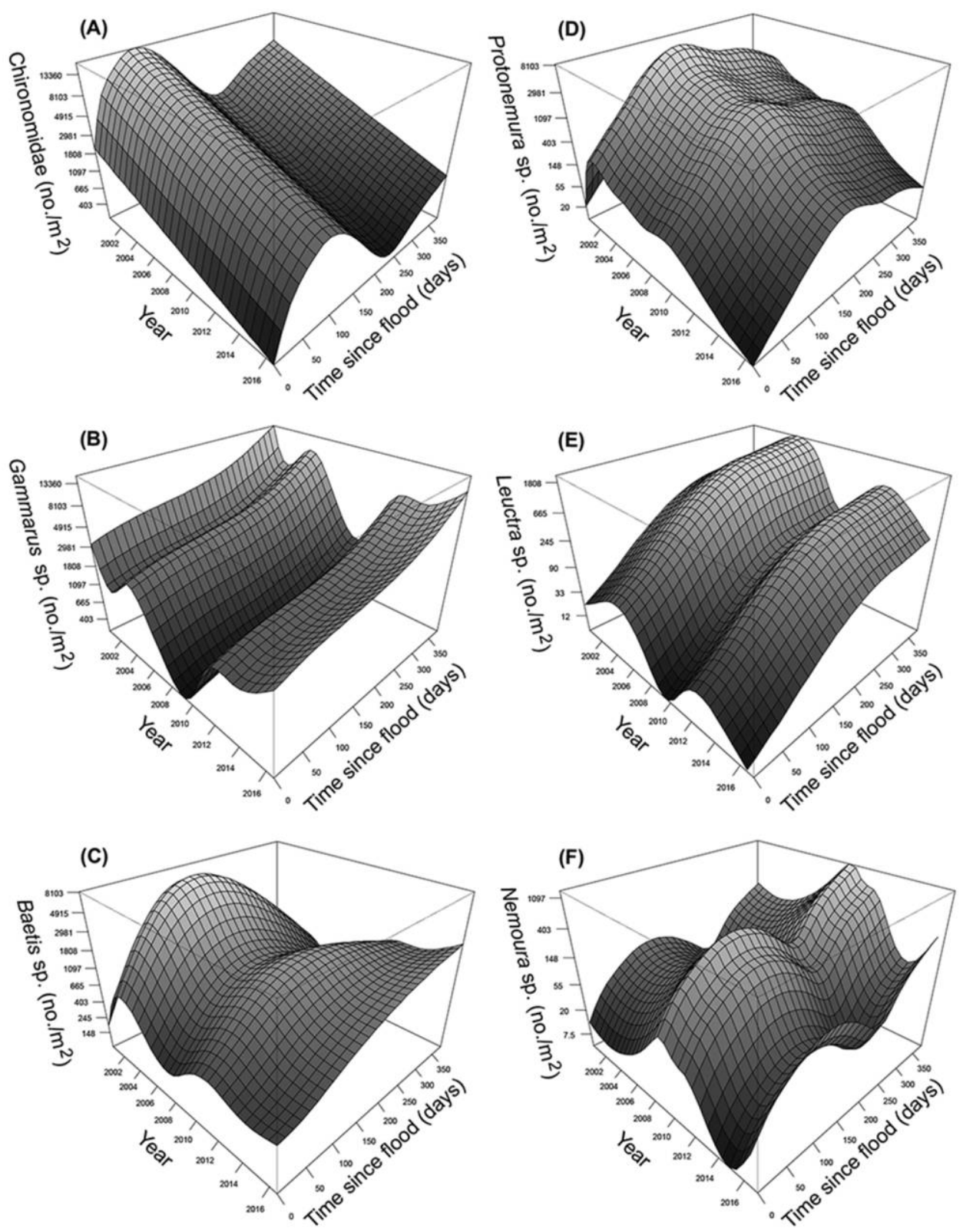

Figure 5. Three-dimensional plots of significant model parameters (generalized additive models [GAMs]) for chironomids (A), Gammarus (B), Baetis (C) mayflies, Protonemura stoneflies (D), Leuctra stoneflies (E), and Nemoura stoneflies (F) densities in the Spöl during the study period. See Table 1 for statistical summary of the GAM results.

(Task Force Spöl 2015). The number of redds remained low in 2014 (23 redds) with an increase to 153 redds in 2016 (Fig. 7).

\section{Selected response variables during the 2013 flood}

The July flood in 2013 was used to flush fine sediments deposited in the study reach from the accidental sediment spill on 30 March of that year. Discharge during this flood began with a gradual increase to $\sim 20 \mathrm{~m}^{3} / \mathrm{s}$ in the initial $2 \mathrm{~h}$, followed by an increase to $30 \mathrm{~m}^{3} / \mathrm{s}$ in the next $2 \mathrm{~h}$ (Fig. $8 \mathrm{~A}$ ). Flow was reduced then to $10 \mathrm{~m}^{3} / \mathrm{s}$ for an initial examination of the river bed and subsequently increased to $\sim 40 \mathrm{~m}^{3} / \mathrm{s}$ for $1 \mathrm{~h}$ before returning to baseflow conditions over the next 2 to $3 \mathrm{~h}$. Turbidity of the river responded similarly to the changes in flow with high values ( $>2000$ NTU) during the initial peak followed by lower values of $\sim 500$ NTU and then high values ( $>1500$ NTU) again when flow was increased to $30 \mathrm{~m}^{3} / \mathrm{s}$ (Fig. 8B). Turbidity then decreased to baseflow levels $(<10 \mathrm{NTU})$ during the low-flow period and increased to $\sim 900$ NTU during the final peak flow of the flood. Transported organic material (seston) increased to $\sim 500 \mathrm{mg} / \mathrm{m}^{3}$ during the initial peak flow, then decreased to low levels with 


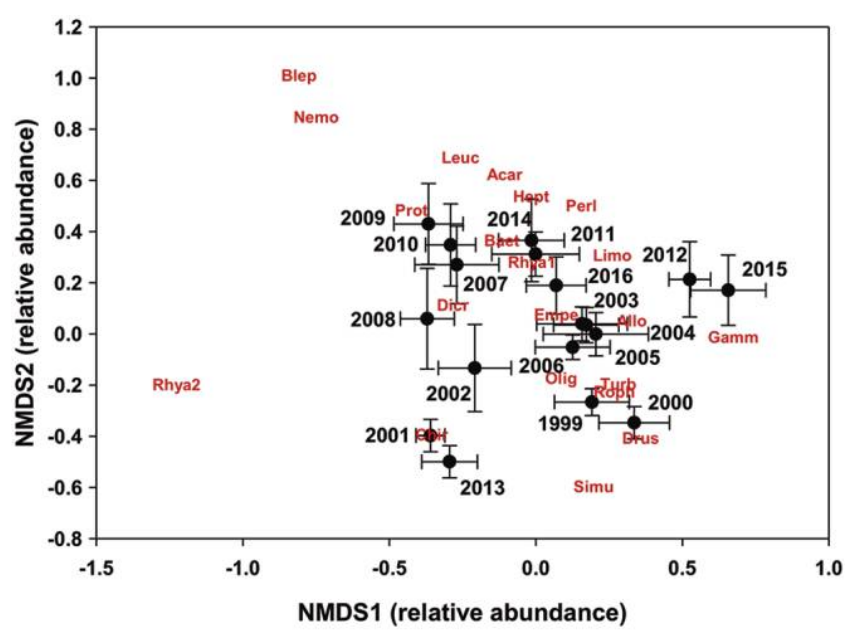

Figure 6. A nonmetric multidimensional scaling (NMDS) plot of macroinvertebrate assemblages in the Spöl during the course of the study based on relative abundance data. Data are plotted as means $( \pm \mathrm{SE})$ for each respective year of the study.

periodic increases to $\sim 100 \mathrm{~m} / \mathrm{m}^{3}$ during the remaining period of the flood (Fig. 8B). In contrast with turbidity, no major increase in seston was observed during the final peak in flow. Drifting macroinvertebrates increased in the initial period of the flood to $\sim 45 \mathrm{ind} / \mathrm{m}^{3}$ and remained high for $\sim 1.5$ to $2.0 \mathrm{~h}$, albeit with a decrease to $\sim 12 \mathrm{ind} / \mathrm{m}^{3}$ after $1 \mathrm{~h}$ during the $1^{\text {st }}$ high flow. Drift returned to low levels after the initial pulse with no major increases during the $2^{\text {nd }}$ or $3^{\text {rd }}$ peak in flow (Fig. 8A).

\section{DISCUSSION}

Long-term monitoring was imperative for elucidating abiotic and biotic response patterns in the Spöl to sequential experimental floods. Some 30 experimental floods ( 1 to $3 / y$ ) were released over the 18 y of study. The flood program is ongoing and part of the regulatory framework of the hydropower scheme in the river (T. Scheurer, Swiss
Academy of Sciences [SCNAT], personal communication), but with contingencies, such as the lack of water in 2005, research purposes in 2010, or the flushing flow of fine sediments in 2013. The floods implemented each year are discussed a priori, usually in January/February, based on available results from previous years and respective needs (research/ administrative) of that particular year. This transparency among interest groups and stakeholders has been the foundation for successful management of experimental flows in the river, e.g., implementation of the Spöl Task Force to discuss best management options following the sediment spill in 2013 (Task Force Spöl 2015).

The experimental floods had minimal effects on the physicochemistry of waters in the river. The floods were produced with hypolimnetic release waters from the reservoir, so no substantial changes in physicochemistry were expected. Any long-term changes probably will arise from regional demographic/landscape alterations and climate-related changes (Robinson 2012, Sertić Perić et al. 2015). Sertić Perić et al. (2015) documented long-term trends for nearby alpine streams monitored during the same time frame as our study, but here we discuss only the results from the Spöl study. In the Spöl, DP concentrations increased in the river since 2012, but showed a similar seasonality to earlier years. $\mathrm{NO}_{3}{ }^{-}$levels also increased by $\sim 50 \mu \mathrm{g} / \mathrm{L}$ after 2009 , but seasonal maxima were similar to those in earlier years. Reservoir effects probably influenced seasonal temperature patterns in the river by mitigating high temperatures in summer and low temperatures in winter (Ward and Stanford 1979). Some lower-than-average winter temperatures were observed in 2005-2006 because drought conditions kept water levels in the reservoir lower than usual (i.e., reservoir residence time was short). However, the storage capacity of large reservoirs may mitigate extreme events (e.g., heatwaves such as in 2003 in Switzerland; Beniston 2004) in downstream waters, especially for hypolimnetic release waters as in the Spöl. The combination of reservoir storage and experimental flow programs may be used to examine the effects of heat waves on

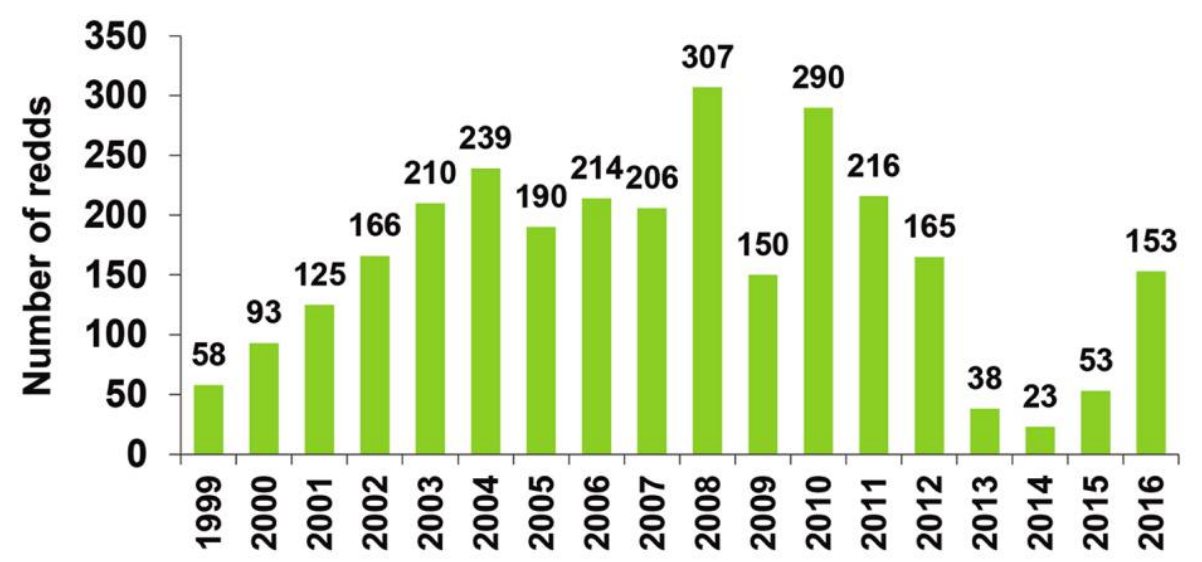

Figure 7. The number of Brown Trout redds counted each year in autumn during the study period. 


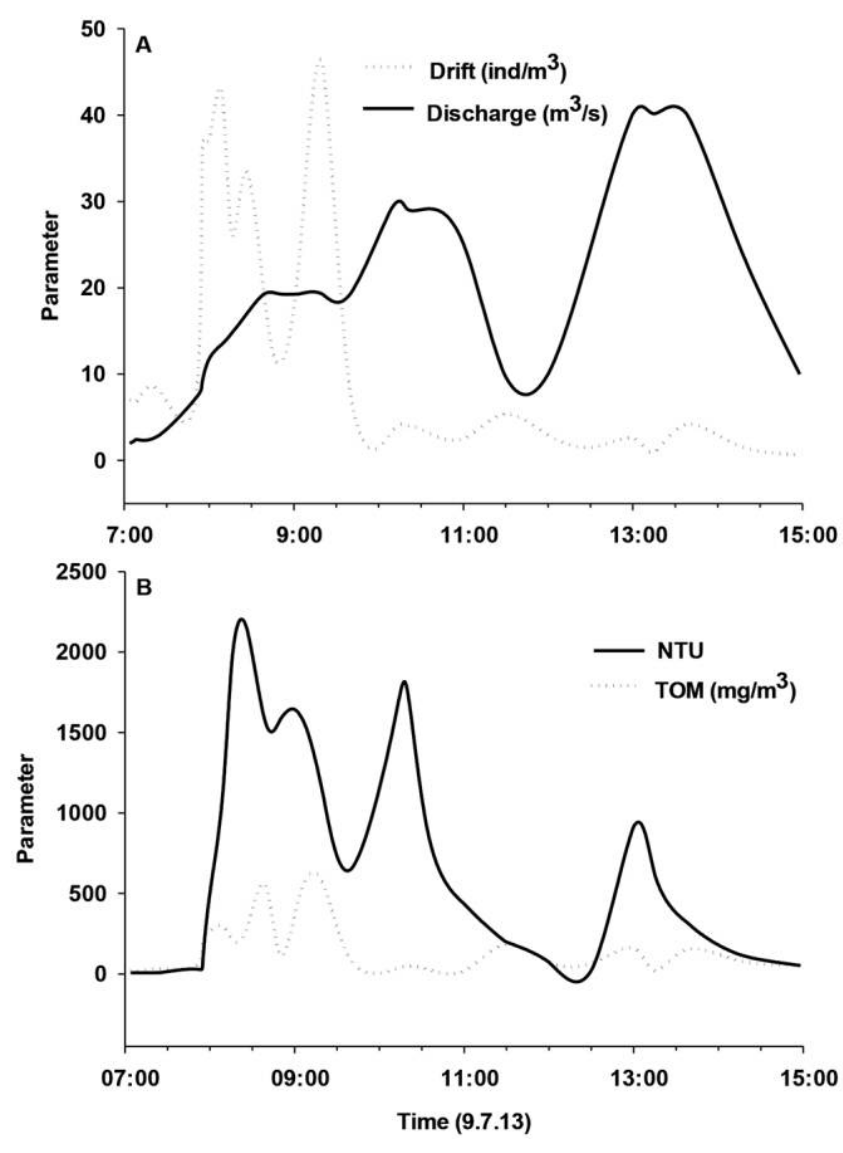

Figure 8. Plots of discharge and macroinvertebrate drift (A) and turbidity and transported organic matter (TOM) (B) during the high flow on 9 July 2013. This particular flood was used to flush fine sediments deposited in the residual section of the river resulting from the sediment spill in March 2013. Ind $=$ individuals.

running waters, particularly with the view that heatwaves are becoming more frequent, intense, and longer in duration (sensu Meehl and Tebaldi 2004). Our analysis also showed that average stream temperatures have increased over the $18 \mathrm{y}$ of study, probably in response to climate warming (although the exact cause is unknown).

Organic-matter resources (seston, periphyton, BOM) all decreased after each experimental flood with subsequent increases between floods. Seston is the organic matter in transport, originating from upstream (e.g., reservoir release waters), instream (e.g., excess benthic production), and lateral inputs (e.g., tributaries or valley side-slopes) (Vannote et al. 1980). Seston reflected changes in periphyton and $\mathrm{BOM}$ in the river. Thus, upstream inputs from the reservoir probably were similar among collection dates (seston collected during floods was not included in the present analysis). In addition, peaks in seston were associated with local precipitation events that increased inputs from small tributaries and flushed organic matter from valley side-slopes
(CTR, ARS, JO, personal observation). Essentially, the experimental floods reduced BOM and periphyton biomass that were linked to the lower levels of seston following each flood. The high interflood levels in periphyton, relative to BOM, indicate that sloughing biofilms may be a large component of the seston in the river, as seen in the Colorado system below Lake Powell (Shannon et al. 1996, Cross et al. 2011). In particular, the high interflood BOM levels in 2000 and 2001 were associated with in-stream moss that was scoured and redistributed in the riverbed during these early floods (Uehlinger et al. 2003) and eventually removed from the system after 2002 (see Robinson and Uehlinger 2008). The higher between-flood seston levels also suggest enhanced food-resource availability to primary consumers (macroinvertebrates), such as collector-gatherers and filter feeders. Seston was mostly fine particulate organic matter (FPOM; CTR, ARS, JO, personal observation).

The experimental floods had no major short-term effects on nutrients $(\mathrm{N}, \mathrm{P})$ in the river, but both $\mathrm{N}$ and $\mathrm{P}$ have increased somewhat during the study period and are not limiting for primary producers. Interflood periods were associated with high periphyton standing stocks (as AFDM), even though a management objective was to reduce periphyton levels in the river toward improving spawning conditions for the Brown Trout. In fact, this result was a primary aim of the autumn floods so that the reproductive potential of spawning trout in October/November would be enhanced by cleansing the river bed (Ortlepp and Mürle 2003). The early floods in the program were important for reducing colmation (embeddedness) in the river by scouring out thick moss beds and flushing fine sediments (Mürle et al. 2003, Robinson et al. 2004). This objective was met successfully within the first 3 y (Uehlinger et al. 2003), whereas later floods were used to mobilize bed sediments to reduce fine sediments and maintain low periphyton levels to minimize colmation (Robinson and Uehlinger 2008). The results clearly indicate that high flows are necessary to reset periphyton levels in the river on a continuous basis because recovery of periphyton from physical disturbance can be rapid (Stevenson 1990, Peterson et al. 1994, Uehlinger 2000), and periphyton can reach levels observed before the flood program within weeks (Robinson and Uehlinger 2008, Robinson 2012, this study).

The floods have successfully reduced the quantity of BOM in the river. $\mathrm{BOM}$ levels before the flood program were typically $>15 \mathrm{~g} \mathrm{AFDM} / \mathrm{m}^{2}$ and decreased to $<10 \mathrm{~g} / \mathrm{m}^{2}$ after the experimental floods were implemented. These BOM values are similar to those found in subarctic streams $\left(20-56 \mathrm{~g} / \mathrm{m}^{2}\right)$ (Harvey et al. 1997, Irons and Oswood 1997) but are $\sim 10 \times$ higher than those found in alpine glacier-fed streams (McKnight and Tate 1997, Uehlinger and Zah 2003, Sertić Perić et al. 2015). The reduction in BOM probably enhanced streambed porosity and improved conditions for trout spawning (Ortlepp and Mürle 2003). BOM typically increased be- 
tween floods, highlighting the role of periodic floods in maintaining low BOM levels (and bed porosity) in the river over time. The increase in BOM between floods was mostly from FPOM (CTR, ARS, JO, personal observation) probably from upstream (i.e., reservoir inputs), tributary, and sideslope contributions. This organic matter resource is available for primary consumers (macroinvertebrates) that feed on detritus (Wallace et al. 1999, Allan and Castillo 2007), but its quality was not assessed in our study.

Individual floods reduced macroinvertebrate densities, and the relative loss was related to flood magnitude (see Robinson 2012). The effect of flood magnitude appears to have a threshold related to floods $>25 \mathrm{~m}^{3} / \mathrm{s}$; these floods had similar reductions in macroinvertebrate numbers. In general, the floods have maintained macroinvertebrate densities at levels lower than found before the flood program in 1999, but with substantial between-flood peaks. These peaks generally occurred in years having only 1 experimental flood (e.g., 2010) or in years when the flood magnitude was $<25 \mathrm{~m}^{3} / \mathrm{s}$ (e.g., 2002). Regardless, the recovery of macroinvertebrate abundance was rapid between floods (within weeks), a result seen by others conducting disturbancerelated studies (Robinson and Minshall 1986, Resh et al. 1988, Imbert and Perry 2000). What is interesting in our study is the continued long-term response of macroinvertebrates to the experimental floods; i.e., the response to floods by macroinvertebrates is repeatable over decades of experimental-flow releases. The individual floods act as a continuous reset mechanism, thereby sustaining ecosystem dynamics over time.

The experimental floods reduced taxonomic richness below preflood levels for the first $7 \mathrm{y}$, indicating a loss of taxa without replacement. Taxonomic richness then increased to preflood levels in 2007, with novel taxa colonizing the system (Robinson 2012). Richness values decreased after each flood (as did densities) but recovered rapidly between floods, indicating enhanced resilience of the system to disturbance. The reduced richness may be related to the lower densities on some sampling dates, i.e., sampling effect, thus the taxa with low abundance may have been present, but not collected. Even so, taxonomic richness was higher than preflood values between 2010 and 2015, before decreasing again after 2015. Robinson (2012) related these changes in taxonomic richness to assemblage shifts in the system over time as more alpine-stream-associated macroinvertebrates began colonizing the river under the new flow (disturbance) regime (see Sertić Perić et al. 2015). This assemblage shift was associated with ecosystem state changes (sensu Scheffer et al. 2001) and an altered habitat template (Southwood 1977, 1988). The pattern of colonization also follows island biogeographic theory (MacArthur and Wilson 1979) of immigration and extinction in fragmented or isolated habitats. For instance, the flow-regulated section of the Spöl is situated in a canyon and is isolated by an upper and lower reservoir complex. Colonizing invertebrates must come from smaller tributaries entering the study section or adults flying across the reservoirs. The experimental floods probably reduced abundances to levels that allowed colonization to occur in less-populated but suitable habitats.

The NMDS analysis supports the regime-shift perspective. The results indicate an assemblage shift in 2001 after the early floods. Other major shifts in macroinvertebrate assemblage occurred in 2003, 2007, and 2011. The catastrophic sediment spill in 2013 reset the assemblage to that found in 2001, but it quickly rebounded to that found in 2011, and assemblages in 2015-2016 remained quite similar in ordination space. Robinson (2012) documented increases in parameter variance during periods of assemblage transition that conform to theoretical indicators of regime shifts in community assembly (Carpenter and Brock 2006). Fish abundances also increased during the initial years and plateaued in 2003. The effect of the fishery, i.e., increased predation on macroinvertebrate assemblage composition may have acted in addition to changes in habitat properties on observed assemblage shifts in the system. The influence of biotic interactions must still be examined in the ecological response patterns of river ecosystems to environmental flows (but see Cross et al. 2011).

Individual taxa responded differentially to the experimental flows over the study period. Besides the loss of taxa, the floods effectively reduced densities of Gammarus in the river. This taxon was especially abundant (up to 20,000 ind/ $\mathrm{m}^{2}$ ) and dominated assemblages in 1999 before the flood program began. Gammarus numbers quickly recovered to high levels in years with single floods or floods $<25 \mathrm{~m}^{3} / \mathrm{s}$, suggesting strong resilience to flow disturbance and highlighting the importance of maintaining a flood program in the river to keep Gammarus abundances low. Gammarus have traits associated with streams with more stable flow conditions in general and have a completely aquatic life cycle. Chironomids responded positively in the early flood years before showing lower abundances after 2003 at $<5000$ ind/ $\mathrm{m}^{2}$ with periodic peaks in some years. Baetis followed a similar pattern as chironomids, responding positively in the early years but maintaining relatively high abundances throughout the study period. Both baetids and chironomids are well known for being disturbance resistant and early colonizers of disturbed stream and rivers (Robinson and Minshall 1986).

Some alpine-related taxa had delayed responses to the experimental flows. Leuctra became common in 2007 (7 y after the study began), and Nemoura gained abundance a year later in 2008. Leuctra has remained abundant in the river since 2007, whereas Nemoura abundances have fluctuated between years since 2008. Both taxa displayed density reductions from the experimental floods with increased densities between floods, indicating a high degree of resilience. Both have terrestrial adult stages in the life cycle and are as- 
sociated with alpine systems with variable flows (Hieber et al. 2005). Protonemoura also showed increased abundances after 2002, but abundance then slowly decreased until 2012 and populations have been maintained at low levels since. However, all 3 taxa are good indicators that the system has shifted to be more alpine in character in terms of habitat characteristics and assemblage composition (see Sertić Perić et al. 2015 for compositional patterns in nearby streams). Disturbance-prone taxa appear to have been replaced by more disturbance-resilient taxa (and associated traits) as found in alpine running waters subject to more frequent (seasonal and periodic) high-flow events (Hieber et al. 2005).

The abundance of Brown Trout, estimated from redd counts (Beland 1996), increased $5 \times$ by $2003, \sim 30+$ redds $/ y$. The number of redds has plateaued at $\sim 200+$, a result suggesting habitat limitation for redds or capacity limit of the system for fish. Fluctuations among years from 2003 to 2013 probably were an artifact of poor visibility for counting redds (JO, personal observation). The sediment spill drastically reduced the number of Brown Trout in the river in 2013, and redd counts became lower than before the flood program. However, the number of redds increased dramatically in 2016 ( $3 \times$ increase), indicating excellent recruitment potential of Brown Trout in the river. Brown Trout start reproducing after $2 \mathrm{y}$ of development in this river (JO, personal observation), thus a delayed recovery compared to macroinvertebrates was expected. The major increase in redd number from 2015 to 2016, compared to the annual increases between 2000 and 2003, further suggests that habitat conditions were suitable for quick recovery; i.e., habitat changes caused by the experimental floods increased the resilience of fish to catastrophic disturbance.

The sediment spill in the river in early 2013 can be considered a major pulse disturbance (Lake 2000). Sediment covered the river bed and caused high mortality of fish and macroinvertebrates. Fish redd counts decreased $\sim 6 \times$ in 2013 and macroinvertebrate assemblages were reset to a composition found in 2001. A sediment flushing flow was implemented in early July 2013 with ecological responses during the high flow similar to those observed during other examined experimental floods in the river (Robinson and Uehlinger 2008, Robinson 2012). The flushing flow was successful in clearing the river bed of deposited fine sediments from the spill (Task Force Spöl 2015). Habitat conditions resulting from the experimental flood program were sustained, thereby facilitating a rapid recovery of the river ecosystem from a pulse disturbance. The rapid recovery shows the resilience of the river to such events is high and that the experimental flow program successfully improved ecological conditions in the river.

Long-term monitoring was essential to our understanding the temporal response of the river to experimental flows (Jackson and Füreder 2006, Gibson-Reinemer et al. 2017).
Furthermore, these data were important for evaluating the effects of a pulse disturbance (large sediment spill) on the river ecosystem. The experimental floods were initiated to improve habitat conditions for the Brown Trout fishery and were quite successful. The changes in in-stream habitat also caused regime shifts in macroinvertebrate assemblages toward a composition more alpine in character (associated with respective species traits). The flow program appears to have increased the resilience of the ecosystem to unpredictable perturbations, although additional tests are necessary to confirm this result. Continuous long-term monitoring yields management insights and helps elucidate ecological surprises arising from environmental flow programs in regulated rivers or rivers undergoing restoration measures.

\section{ACKNOWLEDGEMENTS}

Author contributions: CTR designed the study, collected, and analyzed the data, and wrote the paper; ARS analyzed the data and wrote the paper; JO designed the study, collected data, analyzed the fish aspect of the study, and wrote the paper.

We thank the numerous individuals that assisted in the field during the course of the study. We especially thank C. Jolidon and S. Blaser for field and laboratory assistance throughout the study, and the Aua Lab at Eawag for water chemistry analysis of the water samples. We thank F. Filli and R. Haller for facilitating our research in the Swiss National Park. We thank U. Uehlinger, T. Scheurer, and P. Molinari for initiating the project, and U. Mürle and the Park fishery for fish redd counting and summarizing the fish data. We thank the Kraftwerk Engadine for implementing the high flows each year. Partial funding for sampling during 2013/ 2014 was from the Kraftwerk Engadine. We thank 3 anonymous referees for constructive comments that improved the paper presentation. This paper is dedicated to the memory of Donna M. Anderson, a friend for life.

\section{LITERATURE CITED}

Allan, J. D., and M. M. Castillo. 2007. Stream ecology: structure and function of running waters. Springer, Dordrecht, The Netherlands.

Arthington, A. H. 2014. Environmental flows: saving rivers in the third millennium. University of California Press, Berkeley, California.

Barry, R. C. 1992. Mountain weather and climate. Routledge, London, UK.

Battarbee, R. W., E. M. Shilland, M. Kernan, D. T. Monteith, and C. J. Curtis. 2014. Recovery of acidified surface waters from acidification in the United Kingdom after twenty years of chemical and biological monitoring (1988-2008). Ecological Indicators 37:267-273.

Beland, K. F. 1996. The relation between redd counts and Atlantic salmon (Salmo salar) parr populations in the Dennys River, Maine. Canadian Journal of Fisheries and Aquatic Sciences 53:513-519.

Beniston, M. 2004. The 2003 heat wave in Europe: a shape of things to come? An analysis based on Swiss climatological data and model simulations. Geophysical Research Letters 31:L02202. 
Bunn, S. E., and A. H. Arthington. 2002. Basic principles and ecological consequences of altered flow regimes for aquatic biodiversity. Environmental Management 30:492-507.

Carpenter, S. R., and W. A. Brock. 2006. Rising variance: a leading indicator of ecological transition. Ecology Letters 86:716-726.

Connell, J. H. 1978. Diversity in tropical rain forests and coral reefs. Science 199:1302-1310.

Cross, W. F., C. V. Baxter, K. C. Donner, E. J. Rosi-Marshall, T. A. Kennedy, R. O. Hall, H. A. Wellard Kelly, and R. Scott Rogers. 2011. Ecosystem ecology meets adaptive management: food web response to a controlled flood on the Colorado River, Glen Canyon, USA. Ecological Applications 21:2016-2033.

Death, R. G., I. C. Fuller, and M. G. Macklin. 2015. Resetting the river template: the potential for climate-related extreme floods to transform river geomorphology and ecology. Freshwater Biology 60:2477-2496.

Durance, I., and S. J. Ormerod. 2007. Climate change effects on upland stream macroinvertebrates over a 25 -year period. Global Change Biology 13:942-957.

Foley, M., F. J. Magilligan, C. E. Torgersen, J. J. Major, C. W. Anderson, P. J. Connolly, D. Wieferich, P. B. Shafroth, J. E. Evans, D. Infante, and L. S. Craig. 2017. Response of rivers to dam removal in the United States. PLoS ONE 12:e0180107.

Garssen, A. G., A. Baattrup-Pedersen, L. A. C. J. Voesenek, J. A. Verhoeven, and M. B. Soons. 2015. Riparian plant community responses to increased flooding: a meta-analysis. Global Change Biology 21:2881-2890.

Gibson-Reinemer, D. K., R. E. Sparks, J. L. Parker, J. A. Deboer, M. W. Fritts, M. A. McClelland, J. H. Chick, and A. F. Casper. 2017. Ecological recovery of a river fish assemblage following the implementation of the Clean Water Act. BioScience 67: 957-970.

Gillespie, B. R., S. Desmet, P. Kay, M. R. Tillotson, and L. E. Brown. 2015. A critical analysis of regulated river ecosystem responses to managed environmental flows from reservoirs. Freshwater Biology 60:410-425.

Graf, W. L. 2006. Downstream hydrologic and geomorphic effects of large dams on American rivers. Geomorphology 79:336-360.

Harding, J. S., E. F. Benfield, P. V. Bolstad, G. S. Helfman, and E. B. D. Jones. 1998. Stream biodiversity: the ghost of land use past. Proceedings of the National Academy of Sciences of the United States of America 95:14843-14847.

Harvey, C. J., B. J. Peterson, W. B. Bowden, L. A. Deegan, J. C. Finlay, A. E. Hershey, and M. C. Miller. 1997. Organic matter dynamics in the Kuparuk River, a tundra river in Alaska, USA. Journal of the North American Benthological Society 16:18-22.

Hieber, M., C. T. Robinson, U. Uehlinger, and J. V. Ward. 2005. A comparison of benthic macroinvertebrate assemblages among different types of alpine streams. Freshwater Biology 50:20872100.

Imbert, J. B., and J. A. Perry. 2000. Drift and benthic invertebrate responses to stepwise and abrupt increases in non-scouring flow. Hydrobiologia 436:191-208.

Irons, J. G., and M. W. Oswood. 1997. Organic matter dynamics in 3 subarctic streams of interior Alaska, USA. Journal of the North American Benthological Society 16:23-28.

Jackson, J. K., and L. Füreder. 2006. Long-term studies of freshwater macroinvertebrates: a review of the frequency, duration and ecological significance. Freshwater Biology 51:591-603.
Konrad, C. P., J. D. Olden, D. A. Lytle, T. S. Melis, J. C. Schmidt, E. N. Bray, M. C. Freeman, K. B. Gido, N. P. Hemphill, M. J. Kennard, L. E. McMullen, M. C. Mims, M. Pyron, C. T. Robinson, and J. G. Williams. 2011. Large-scale flow experiments in managing water resources. BioScience 61:948-959.

Lake, P. S. 2000. Disturbance, patchiness, and diversity in streams. Journal of the North American Benthological Society 19:573592.

Lake, P. S., N. Bond, and P. Reich. 2007. Linking ecological theory with steam restoration. Freshwater Biology 52:597-615.

Lytle, D. A., and N. L. Poff. 2004. Adaptation to natural flow regimes. Trends in Ecology and Evolution 19:94-100.

MacArthur, R. H., and E. O. Wilson. 1979. The theory of island biogeography. Princeton University Press, Princeton, New Jersey.

Matthews, W. J., E. Marsh-Matthews, R. C. Cashner, and F. Gelwick. 2013. Disturbance and trajectory of change in a fish community over four decades. Oecologia 173:955-969.

McKnight, D. M., and C. M. Tate. 1997. Canada Stream: a glacial meltwater stream in Taylor Valley, South Victoria Land, Antarctica. Journal of the North American Benthological Society 16:14-17.

McMullen, L. E., and D. A. Lytle. 2012. Quantifying invertebrate resistance to floods: a global-scale meta-analysis. Ecological Applications 22:2164-2175.

Meehl, G. A., and C. Tebaldi. 2004. More intense, more frequent, and longer lasting heat waves in the $21^{\text {st }}$ century. Science 305: 994-997.

Mürle, U., J. Ortlepp, and M. Zahner. 2003. Use of experimental flooding to enhance river integrity below a large dam: sediment processes and changes in geomorphology, habitat structure and riparian vegetation. Aquatic Sciences 65:191-198.

Nilsson, C., C. A. Reidy, M. Dynesius, and C. Revenga. 2005. Fragmentation and flow regulation of the world's large river systems. Science 308:405-408.

Olden, J. D., C. P. Konrad,, T. S. Melis, M. J. Kennard, M. C. Freeman, M. C. Mims, E. N. Bray, K. B. Gido, N. P. Hemphill, D. A. Lytle, L. E. McMullen, M. Pyron, C. T. Robinson, J. C. Schmidt, and J. G. Williams. 2014. Are large-scale flow experiments informing the science and management of freshwater ecosystems? Frontiers in Ecology and Environment 12:176-185.

Olden, J. D., and R. J. Naiman. 2010. Incorporating thermal regimes into environmental flows assessments: modifying dam operations to restore freshwater ecosystem integrity. Freshwater Biology 55:86-107.

Opperman, J. J., R. Luster, B. A. McKenney, M. Roberts, and A. W. Meadows. 2010. Ecologically functional floodplains: connectivity, flow regime, and scale. Journal of the American Water Resources Association 46:211-226.

Ortlepp, J., and U. Mürle. 2003. Effects of experimental flooding on brown trout (Salmo trutta fario L.): the Spöl River, Swiss National Park. Aquatic Sciences 65:232-238.

Peterson, C. G., A. C. Weibel, N. B. Grimm, and S. G. Fisher. 1994. Mechanisms of benthic algal recovery following spates: comparison of simulated and natural events. Oecologia 98:280-290.

Pickett, S. T. A., and P. S. White. 1985. The ecology of natural disturbance and patch dynamics. Academic Press, New York.

Poff, N. L., J. D. Allan, M. B. Bain, J. R. Karr, K. L. Prestegaard, B. D. Richter, R. E. Sparks, and J. C. Stromberg. 1997. The natural flow regime. BioScience 47:769-784. 
Poff, N. L., J. D. Olden, D. M. Merritt, and D. M. Pepin. 2007. Homogenization of regional river dynamics by dams and global biodiversity implications. Proceedings of the National Academy of Sciences of the United States of America 104:5732-5737.

Resh, V. H., A. V. Brown, A. P. Covich, M. E. Gurtz, H. W. Li, G. W. Minshall, S. R. Reice, A. L. Sheldon, J. B. Wallace, and R. C. Wissmar. 1988. The role of disturbance in stream ecology. Journal of the North American Benthological Society 7:433455.

Reid, M. A., and R. W. Ogden. 2006. Trend, variability or extreme event? The importance of long-term perspectives in river ecology. River Research and Applications 22:167-177.

Riebe, C. S., L. S. Sklar, B. T. Overstreet, and J. K. Wooster. 2014. Optimal reproduction in salmon spawning substrates linked to grain size and fish length. Water Resources Research 50:1-21.

Robertson, A. L., L. E. Brown, M. J. Klaar, and A. M. Milner. 2015. Stream ecosystem responses to an extreme rainfall event across multiple catchments in southeast Alaska. Freshwater Biology 60:2523-2534.

Robinson, C. T. 2012. Long-term changes in community assembly, resistance, and resilience following experimental floods. Ecological Applications 22:1949-1961.

Robinson, C. T., S. Aebischer, and U. Uehlinger. 2004. Immediate and habitat-specific responses of macroinvertebrates to sequential experimental floods. Journal of the North American Benthological Society 23:853-867.

Robinson, C. T., and G. W. Minshall. 1986. Effects of disturbance frequency on stream benthic community structure in relation to canopy cover and season. Journal of the North American Benthological Society 5:237-248.

Robinson, C. T., and U. Uehlinger. 2008. Experimental floods cause ecosystem regime shift in a regulated river. Ecological Applications 18:511-526.

Robinson, C. T., U. Uehlinger, and M. T. Monaghan. 2003. Effects of a multi-year experimental flood regime on macroinvertebrates downstream of a reservoir. Aquatic Sciences 65:210222.

Rood, S. B., G. M. Samuelson, J. H. Braatne, C. R. Gourley, F. M. R. Hughes, and J. M. Mahoney. 2005. Managing river flows to restore floodplain forests. Frontiers in Ecology 3:193-201.

Scheffer, M., S. Carpenter, J. A. Foley, C. Folke, and B. Walker. 2001. Catastrophic shifts in ecosystems. Nature 4113:591-596.

Scheurer, T., and P. Molinari. 2003. Experimental floods in the River Spöl (Swiss National Park): framework, objectives and design. Aquatic Sciences 65:183-190.

Sertić Perić, M., C. Jolidon, U. Uehlinger, and C. T. Robinson. 2015. Long-term ecological patterns of alpine streams: an imprint of glacial legacies. Limnology and Oceanography 60:9921007.

Shannon, J. P., D. W. Blinn, P. L. Benenati, and K. P. Wilson. 1996. Organic drift in a regulated desert river. Canadian Journal of Fisheries and Aquatic Sciences 53:1360-1369.

Southwood, T. R. E. 1977. Habitat, the templet for ecological strategies. Journal of Animal Ecology 46:337-365.
Southwood, T. R. E. 1988. Tactics, strategies, and templets. Oikos 52:3-18.

Stevenson, R. J. 1990. Benthic algal community dynamics in a stream during and after a spate. Journal of the North American Benthological Society 9:277-288.

Task Force Spöl. 2015. Schlussbericht Umweltunfall Spöl. Swiss National Park report, HYDRA AG, St Gallen, Switzerland.

Thompson, R. M., J. Beardall, J. Beringer, M. Grace, and P. Sardina. 2013. Means and extremes: building variability into communitylevel climate change experiments. Ecology Letters 16:799806.

Tockner, K., F. Malard, P. Burgherr, C. T. Robinson, U. Uehlinger, R. Zah, and J. V. Ward. 1997. Physico-chemical characterization of channel types in a glacial floodplain ecosystem (Val Roseg, Switzerland). Archiv für Hydrobiologie 140:433-463.

Uehlinger, U. 1991. Spatial and temporal variability of the periphyton biomass in a prealpine river (Necker, Switzerland). Archiv für Hydrobiologie 123:219-237.

Uehlinger, U. 2000. Resistance and resilience of ecosystem metabolism in a flood-prone river system. Freshwater Biology 45: 319-332.

Uehlinger, U., B. Kawecka, and C. T. Robinson. 2003. Effects of experimental floods on periphyton and stream metabolism below a high dam in the Swiss Alps (River Spöl). Aquatic Sciences 65:199-209.

Uehlinger, U., and R. Zah. 2003. Organic matter dynamics. Pages 199-216 in J. V. Ward and U. Uehlinger (editors). Ecology of a glacial flood plain. Kluwer Academic Publishers, Dordrecht, The Netherlands.

Vannote, R. L., G. W. Minshall, K. W. Cummins, J. R. Sedell, and C. E. Cushing. 1980. The river continuum concept. Canadian Journal of Fisheries and Aquatic Sciences 37:130-137.

Vörösmarty, C. J., P. B. McIntyre, M. O. Gessner, D. Dudgeon, A. Prusevich, P. Green, S. Glidden, S. Bunn, S. E. Sullivan, C. A. Reidy, C. Liermann, and P. M. Davies. 2010. Global threats to human water security and river biodiversity. Nature 467: 555-561.

Wallace, J. B., S. L. Eggert, J. L. Meyer, and J. R. Webster. 1999. Effects of resource limitation on a detrital-based ecosystem. Ecological Monographs 69:409-442.

Ward, J. V., and J. A. Stanford. 1979. The ecology of regulated streams. Plenum Press, New York.

Wohl, E., B. P. Bledsoe, R. B. Jacobson, N. L. Poff, S. L. Rathburn, D. M. Walters, and A. C. Wilcox. 2015. The natural sediment regime in rivers: broadening the foundation for ecosystem management. BioScience 65:358-371.

Woodward, G., N. Bonada, H. B. Feeley, and P. S. Giller. 2015. Resilience of a stream community to extreme climatic events and long-term recovery from catastrophic flood. Freshwater Biology 60:2497-2510.

Yarnell, S. M., G. E. Petts, J. C. Schmidt, A. A. Whipple, E. E. Beller, C. N. Dahm, P. Goodwin, and J. H. Viers. 2015. Functional flows in modified riverscapes: hydrographs, habitats and opportunities. BioScience 65:963-972. 